\section{An Economy's Emergent Properties and How Micro Agents with Inconsistent or Conflicting Interests Are Holistically Organized into Macro Entities}

\author{
Jeffrey Yi-Lin Forrest \\ Slippery Rock University, Department of Accounting Economics Finance, \\ USA \\ jeffrey.forrest@sru.edu

\section{Zaiwu Gong} \\ Nanjing University of Information Science and Technology, School of \\ Management Science and Engineering, China \\ zwgong26@163.com
}

\section{Erkan Köse}

Nuh Naci Yazgan University, Industrial Engineering Department, Turkey ekose@nny.edu.tr

\section{Diane D. Galbraith}

Slippery Rock University, Department of Management and Marketing, USA

diane.galbraith@sru.edu

\section{Oğuzhan A. Arık}

Nuh Naci Yazgan University, Industrial Engineering Department, Turkey oaarik@nny.edu.tr

\begin{abstract}
The existing literature documents that computer simulations can reveal how characteristics of micro-level individuals give rise to macro-level phenomena of systemic wholes. This paper seeks to establish such an important simulation-based observation as a theoretical result on a sound foundation. Going beyond addressing when holistic phenomena can naturally emerge from micro-level characteristics, this paper investigates how and why many macro-level entities appear to answer market calls through organically gathering micro-level agents into uniformly-oriented operational wholes, even though these agents have inconsistent or even conflicting interests. This paper develops conclusions based on results of systems science and establishes a sufficient condition under which characteristics of micro-level agents can naturally lead to the appearance of macro-level properties of a systemic whole even though the former are heterogeneous and behave in an
\end{abstract}

REVIEW PAPER

RECEIVED: APRIL 2021

REVISED: AUGUST 2021

ACCEPTED: SEPTEMBER 2021

DOI: $10.2478 /$ ngoe-2021-0017

UDK: 339.13:005.2

JEL: B41, C65

Citation: Forrest Yi-Lin, J., Gong, Z., Köse, E., Galbraith, D. D., \& Oğuzhan, A. A. (2021). An Economy's Emergent Properties and How Micro Agents with Inconsistent or Conflicting Interests Are Holistically Organized into Macro Entities. Naše gospodarstvo/Our Economy, 67(3), 5366. DOI: 10.2478/ngoe-2021-0017.

\section{NG OE}

NAŠE GOSPODARSTVO OUR ECONOMY

Vol. 67 No. 32021

pp. 53-66 
unintended and uncoordinated manner. This paper suggests to root each theoretical result of economics on elementary facts of personal belief-value systems and expands methods of networks and computer simulations to those of systems science. It explains when macro socioeconomic phenomena emerge out of unintended and uncoordinated actions and interactions of micro economic men, and provides a more general approach for developing reliable conclusions than those observed from computer simulations. It additionally derives conditions for when macro-level economic entities appear to answer market calls and how micro-level individuals with inconsistent or even conflicting interests can be organically congregated into operational business organizations.

Keywords: Competition; emergence; holistic phenomena; market signal; system; value; yoyo model

\section{Introduction}

Since the time when the Great Recession occurred in 2008, scholars have realized that the currently available economic theories can neither predict the imminent arrival of a crisis nor help understand the underlying mechanism behind the originating imbalances that eventually led to the devastating consequences regarding unemployment and the real economy. To possibly overcome this recognized deficit in the relevant knowledge, the Oxford Review of Economic Policy developed a "Rebuilding Macroeconomic Theory Project" (Vines \& Wills, 2018). The project examined a set of 6 broadly-based questions related to the benchmark New Keynesian DSGE (Dynamic Stochastic General Equilibrium) model (Smets \& Wouters, 2007). The authors focused on ways to improve or completely replace the benchmark model with another one; and the scholars involved in the project did not believe that a paradigm shift was needed, only perhaps enriching, and improving the formulas of the model (Vines \& Wills, 2018).

In contrast, a team of scholars from Italy proposes to embrace a paradigm shift by employing the theory and methods of complexity science (Delli Gatti et al., 2010). Specifically, they suggest applying the concept of complex networks and computer simulations instead of the current reductionist approach at the heart of the mainstream DSGE models. They demonstrate that computational techniques can vividly simulate the natural emergence of macro-level phenomena from unintended and uncoordinated behaviors of micro-level individuals when they follow some simple rules of action, such as financial contagion (Allen \& Gal, 2000), trade-credit relationships (Boissay, 2006; Battiston et al., 2007).

These two strings of efforts reveal a divergence of beliefs and logics of thinking in terms of how the community of economists should work in the coming years or even decades:
- Gradually enrich the benchmark New Keynesian DSGE model so that it can better predict forthcoming economic crises, provide more appropriate policy suggestions, etc.; or

- Radically adopt a revolutionary new approach so that the consequent theories will be mostly different from those currently available, and the methods employed are powerful and effective, both theoretically and practically.

According to Vines and Wills (2018, p. 5), a paradigm shift in an economic theory means drastic changes in both the content of the theory and the method employed to develop the theory. Hence, this paper supports the Italian team's recognition of a forthcoming paradigm shift in economic theories in general and macroeconomics in particular (Delli Gatti et al., 2011). Specifically, in terms of contents, this paper suggests rooting each and every theoretical result of economics on some of the elementary facts of personal systems of beliefs and values, as suggested by Forrest et al. (2020). And, in terms of methods used to develop theoretical results, this work expands those of networks and computer simulations, as suggested by the Italian colleagues (Delli Gatti et al., 2010), to all methods of systems science established for studying organizations, evolutions and interactions of organizations (Forrest et al., 2013).

Other than the holistic view of this work in the previous paragraph in comparison with the literature along the two lines given above, the main contributions of this paper are outlined below. First, it employs the concept of centralized systems to theoretically explain when macro socioeconomic phenomena emerge out of unintended and uncoordinated actions and interactions of micro economic men. Such rigorously established conclusions are surely more general and reliable than those observed from computer simulations, such as those developed by Allen and Gal (2000), Boissay (2006), Battiston et al. (2007), and many others. The reason is that each computer simulation-based observation is constrained by specified parametric values. Second, other than converting simulation-based observations into theoretical conclusions, this paper shows how to establish conditions for when macro-level economic entities appear to answer market calls and how micro-level individuals with inconsistent or even conflicting interests can be organically congregated into operational business organizations. The importance of this end cannot be overemphasized in light of the trend of developing macroeconomic results on microfoundations, where macro-level conclusions need to be founded on micro-level components (Blanchard, 2018; Lucas, 1976).

The rest of the paper is organized as follows. Section 2 investigates how macro-level holistic phenomena can naturally appear out of the properties of micro-level components. Section 3 demonstrates that other than the emergence of macro-level phenomena out of unintended and uncoordinated micro-level properties, the business world consists of many purposively organized macro-level entities by making use of micro-level components, which generally 
have inconsistent or even conflicting interests. Section 4 concludes this paper with ideas for possible future research.

\section{Systemic Centralisability and Emergence of Holistic Phenomena}

This section analyses the concept of systemic centralisability and ways that it can be employed to explain the emergence of macro socioeconomic phenomena from unintended and uncoordinated actions and interactions of micro economic men (Delli Gatti et al., 2010; Farmer \& Foley, 2009).

\section{Relevant terminologies of systems science}

For our purpose in this paper, this section only introduces concepts of systems relevant to the discussion in the following paragraphs. For a more systematic study of systems science, please consult jointly with Forrest (2018), Forrest et al. (2013), Klir (2001), each of which emphasizes a different aspect of the particular science.

By system, it means a whole, or an organization, or a structure, where micro-level parts or components are somehow associated with one another to form an organically functional macro-level entity. Historically, this concept can be traced back to the very start of the recorded human history (von Bertalanffy, 1968). To derive useful results and develop scientifically sound theories of systems, various particular specifications of this concept have been introduced by diverse authors for a myriad of purposes (Klir, 2001). Among the most productive is the following specification: $S$ is a system, if and only if $S$ is an ordered pair $(M, R)$ of sets, where $\mathrm{M}$ consists of all objects of the system $\mathrm{S}$ and $\mathrm{R}$ all relations that associate the component objects in the object set $\mathrm{M}$ in the formation of the system $\mathrm{S}$. That is, each element in the relation set $\mathrm{R}$ is a relation defined on the object set $\mathrm{M}$ (Lin, 1987). Notice that elements in the object set $M$ are not specified in this definition. Therefore, some of these elements can also be systems themselves. When this happens, this definition of systems reflects the relationship between microlevel economic men (and their individually different characteristics and functionalities) and macro-level business entities (and their holistic interactions).

This very idea that some objects of a system may also be systems themselves is depicted in Figure 1. In particular, the system of the macro-level is $S=(M, R)$, where each object in $\mathrm{M}$ is shown as a dot, while the set $R$ consists of four relations $r_{1}, r_{2}, r_{3}$ and $r_{4}$, each of which is shown as an enclosed area. As depicted, objects $O_{\mathrm{i}}=\left(M_{\mathrm{i}}, R_{\mathrm{i}}\right)$ and $O_{\mathrm{j}}=\left(M_{\mathrm{j}}, R_{\mathrm{j}}\right)$ in set $M$ are also systems. This systemic intuition readily reveals the following fact: the macro-level relations $r_{1}, r_{2}, r_{3}$ and $r_{4}$ may or may not be determined or influenced by the micro-level relations in $O_{\mathrm{i}}$ and in $O_{\mathrm{j}}$. This observation will be shown in Section 3 below.

For a given system $S=(M, R)$, it is said to be trivial if $M=\varnothing$; that is, the object set is empty. This concept of trivial systems is needed for theoretical reasonings, such as the study of interactions of systems, as for the same reason that the concept of zero is necessary in the study of numbers. For two systems $S_{i}=\left(M_{i}, R_{i}\right), i=1,2$, they are equal or identical, denoted $S_{1}=S_{2}$, provided that their objects sets and relation sets are the same. Symbolically, $S_{1}=S_{2}$, if and only if

$M_{1}=M_{2}$ and $R_{1}=R_{2}$.

Figure 1. Appearance of object systems

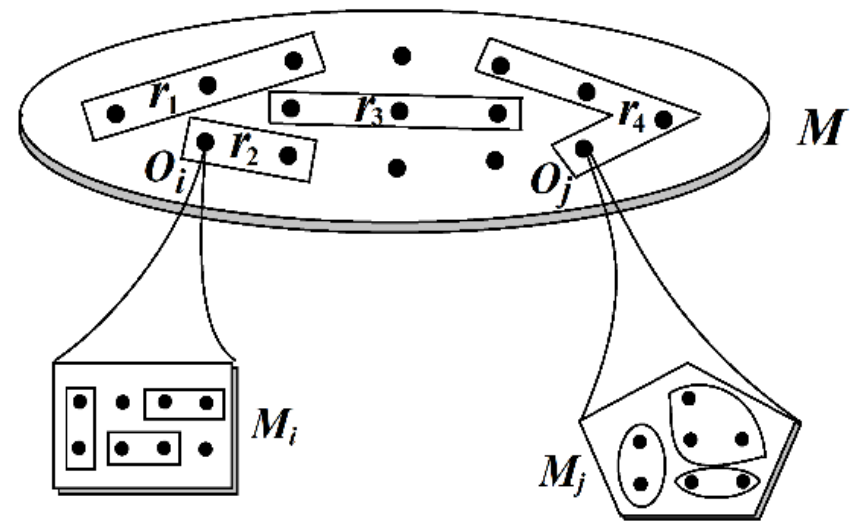

System $S_{1}$ is said to be a partial system of the system $S_{2}$, if $M_{1} \subseteq M_{2}$ and for each relation $r_{1} \in R_{1}$ there exists a relation $r_{2} \in R_{2}$ such that $r_{1}=r_{2} \mid M_{1}$, where $r_{2} \mid M_{1}$ is the restriction of $r_{2}$ on $M_{1}$, which is defined by

$r_{2} \mid M_{1}=r_{2} \cap M_{1}^{n\left(r_{2}\right)}$

where $M_{1}^{n\left(r_{2}\right)}$ is the set of all strings of elements from $M_{1}$ of length $n\left(r_{2}\right)$. For example, $M_{1}^{3}=\left\{\left(m_{1}, m_{2}, m_{3}\right): m_{i} \in\right.$ $\left.M_{1}, i=1,2,3\right\}$.

A system $S=(M, R)$ is referred to as centralized, provided that (a) each object in $M$ is a system, and (b) there exists a nontrivial system $C=\left(M_{C}, R_{C}\right)$ such that for any distinct elements $x, y \in M$, say $x=\left(M_{x}, R_{x}\right)$ and $y=\left(M_{y}, R_{y}\right)$, the following hold true:

$M_{C}=M_{x} \cap M_{y}$ and $R_{C} \subseteq R_{x}\left|M_{C} \cap R_{y}\right| M_{C}$,

where

$R_{x} \mid M_{C}=\left\{r \mid M_{C}: r \in R_{x}\right\}$ and $R_{y} \mid M_{C}=\left\{r \mid M_{C}: r \in R_{y}\right\}$

System $C$ is referred to as a centre of the centralized system $S$. The concept of centralized systems was initially introduced by Hall and Fagen (1956) to describe such a system in that one object or a subsystem plays a dominant role in the system's operation. The leading part can be thought of as the centre of the system, because when it changes slightly it affects the entire system, causing considerable alterations. Figure 2 shows the structure of a centralized system $S=(M, R)$ with center $C=\left(M_{C}, R_{C}\right)$, where for any chosen objects $O_{i}=\left(M_{i}, R_{i}\right), O_{j}=\left(M_{j}, R_{j}\right)$ and $O_{k}=\left(M_{k}, R_{k}\right)$ of $S$, the following hold true: $M_{s}=m_{s} \cup$ 
$M_{C}$ and $m_{s} \cap M_{C}=\emptyset, s=i, j, k$, for some sets $m_{s}, s=$ $i, j, k$.

Figure 2. The structure of a centralized system

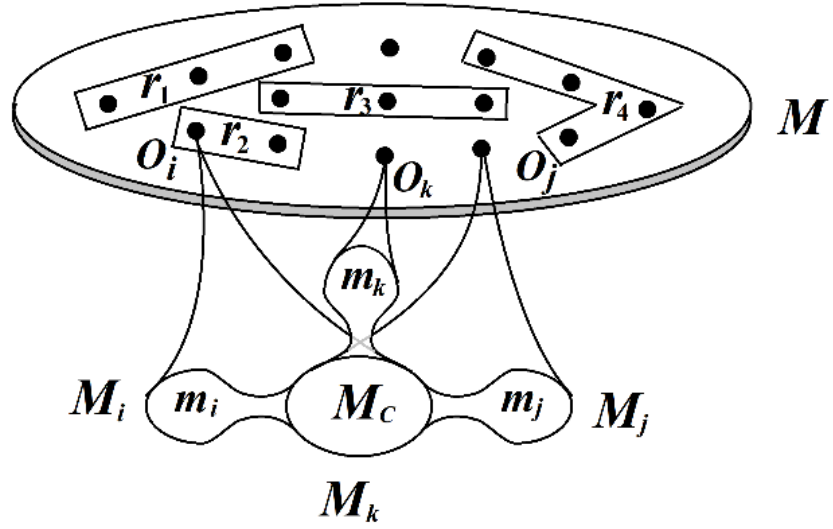

Assume that $\kappa$ and $\theta$ are two given cardinalities satisfying that $\theta$ is regular, and for any $\alpha<\theta,\left|\alpha^{<\kappa}\right|<\theta$, where $\alpha^{<\kappa}=$ $\{\{f: \lambda \rightarrow \alpha\}: \lambda<\kappa\}$ and $|X|$ stands for the cardinality of the set $X$. For relevant concepts of set theory, see Kuratowski and Mostowski (1976). Assume that $S=(M, R)$ is a given system that satisfies: (i) $|M| \geq \theta$, (ii) each object $m=$ $\left(M_{m}, R_{m}\right) \in M$ is also a system, and (iii) for any $m=$ $\left(M_{m}, R_{m}\right) \in M,\left|M_{m}\right|<\kappa$. Then in the language of systems science, the following result holds true:

Theorem 1. If at least $\theta$ objects in the object set $M$ of the system $S$ contains a common element, then $S$ has a partial system $S^{C}=\left(M^{C}, R^{C}\right)$ such that $S^{C}$ forms a centralized system and $\left|M^{C}\right| \geq \theta$.

This systemic result is initially shown in (Lin, 1999). For related discussions on applications of this result in business research see Forrest (2018).

In order for us to apply this result to address our concerns here, let us specify this very general conclusion by letting $\theta=c$ and $\kappa=\aleph_{0}$, where $c$ is the cardinality of the set of all real numbers and $\aleph_{0}$ the cardinality of the set of all natural numbers. Consequently, the assumption above reduces to the following condition: A given system $S=(M, R)$ satisfies (i) $|M| \geq c$, (ii) each object of $S$ is also a system with a finite number of objects. Then, Theorem 1 becomes:

Corollary 1. If there is such an element that belongs to at least $c$ objects in $M$, then system $S$ has a partial system $P=$ $\left(M_{P}, R_{P}\right)$ satisfying that $\left|M_{P}\right| \geq c$ and $P$ is a centralized system.

This result was initially given by Lin (1988) when he attempted to explain two sociological phenomena systemically.

In the following subsection, we will examine how this corollary can help us explain macro-level phenomena that naturally appear out of micro-level properties of individual component parts. Or, we will look at how a system's holistic properties can emerge out of seemingly unintended and uncoordinated actions and interactions of the system's objects.

\section{Macro-Level Phenomena Emerging Naturally from Micro-Level Properties}

To see how the previously listed results of systems theory can be employed to confirm the appearance of macro-level phenomena, emerging out of unintended and uncoordinated micro-level individual desires, let us detail our analysis of Schelling's (1969) example of racial segregation in cities. In this well-regarded work, Schelling shows that when people are allowed to choose which neighbourhoods they live in, each person's relatively insignificant preference for neighbours of his/her own type can, and generally does, lead to macro-level residential segregation through individually and locally repeated housing decisions. In other words, individual's purposive desires of finding neighbours with slightly similar characteristics and behaviours, although they are not coordinated, can possibly lead to the emergence of racial segregations in cities. In such a situation, the emerged segregation is a holistic property of the city as a system, while individual persons' desires and relevant behaviours are properties of the component level. This end reaffirms the cliche that 'birds of a feather flock together.'

Suppose that $A$ is a set of people and $A^{<\omega}$ is the collection of all finite subsets of people in $A$. Then for any finite subset, three possibilities exist:

(1) There is no relation that associates the people in $x$ in any way.

(2) There is exactly one relation that connects the people in the subset $x$; and

(3) There is more than one relation that links the people in $x$.

For situation (1), we construct a system $S_{x}=(x, \emptyset)$, where the relation set contains no element. For scenario (2), we build a system $S_{x}=\left(x, R_{x}\right)$ as follows: in the relation set $R_{x}$, there is only one element that depicts the relationship among the people in the finite set $x$. For the case (3), we construct a collection of systems:

$\left\{S_{x}^{i}=\left(x, R_{x}^{i}\right): i \in I_{x}\right\}$,

where $I_{x}$ is an index set that depends on the finite subset $x$, so that $I_{x}$ and the collection of all relations between the people in subset $x$ are correspondent one-to-one to each other; that is, for any $i \in I_{x}$, the relation set $R_{x}^{i}$ contains only one element that describes an existing relationship between the people in $x$; and conversely, for any relationship $g$ between the people in $x$, there is exactly one $i \in I_{x}$ satisfying that the relation set $R_{x}^{i}$ of system $S_{x}^{i}=\left(x, R_{x}^{i}\right)$ contains exactly one element $r_{g}$ that describes $g$. For scenarios (2) and (3), let the set of all existing relations between the people in 
$x \in \mathrm{A}^{<\omega}$ be denoted as $C^{x}$. Then, scenario (2) is equivalent to $\left|C^{x}\right|=1$, and scenario (3) is equivalent to $\left|C^{x}\right|>1$.

Next, let us consider the particular system $S=(M, \emptyset)$ with an empty relation set so that

$M=\left\{S_{x}: x \in A^{<\omega}\left(\left|C^{x}\right| \leq 1\right)\right\} \cup\left\{S_{x}^{i}=\left(x, R_{x}^{i}\right): x \in\right.$ $\left.A^{<\omega}, i \in I_{x}\left(\left|C^{x}\right|>1\right)\right\}$.

Now, Corollary 1 says that if (i) the cardinality $|M| \geq c$, and (ii) there exists at least one person from $A$ who belongs to at least $c$ many object systems in $M$, then there exists a subset $M^{C} \subseteq M$ such that $S^{C}=\left(M^{C}, \varnothing\right)$ forms a centralized system and $\left|M^{C}\right| \geq c$.

The construction of the system $S=(M, \emptyset)$ implies that condition (i) means that there exists a complicated network of relationships among the people in $A$; and condition (ii) implies that there exists at least one person in $A$ who is sufficiently associated with the other people in $A$. When studying the network of relationships among people in an economy, condition (i) can be seen as satisfied without much doubt, while condition (ii) surely holds true if we look at a prominent politician. More specifically, when one studies economic issues that involve a set $A$ of people, the sophistication of the network of relationships among the people can be measured by the number of mathematicallydefined relations (Lin, 1999, p. 97) as follows: if $r$ describes a relation between and among the people in $A$, then there is an ordinal number $n=n(r)$, a function in $r$, such that $r \subseteq$ $A^{n}$, where

$$
A^{n}=\underbrace{A \times A \times \ldots \times A}_{n \text { times }}=\{f: f \text { is a mapping } n \rightarrow A\} .
$$

That is, to apply Corollary 1 with all necessary rigor, one needs to rewrite each relation between people in the language of set theory. In particular, each relation must be written in such a way that it consists of the following basic blocks only: " $x$ is a set," " $x \in y$," " $x=y$," "and," "or," "if ... then," "if and only if." For details see (Kuratowski \& Mostowski, 1976). Because of this requirement, we can generally say based on Corollary 1 that as long as a particular human desire appears in the minds of a sufficiently large number of people and these people materially act to realize the desire in real life, then a partial system of sufficient scale of the whole system will reflect the realization of the desire. In other words, for a micro-level desire to blossom into a macro-level phenomenon, even for the case that people with the desire behave uncoordinatedly, the following condition must be met: the people with the particular desire engage in a large number of actions for the purpose of materializing the desire in real life.

In short, a condition for a micro-level desire of the component parts of an economy to eventually lead to the emergence of a macro-level characteristic of the entire economy is the following: a large population of people possess that desire and proactively engage in efforts to materialize the desire, even though they act uncoordinatedly.
Now, let us look at Schelling's (1969) example of racial segregation in cities. In this case, especially in the past in America, the majority of the population felt comfortable to have people of their own type as neighbours, while people were allowed to repeatedly relocate. Evidently, each relocation presented an opportunity for relocators to materialize their desires, which are either spoken or unspoken. Corollary 1 implies that such deeply-rooted desire in individual minds of the population and opportunities for individuals to make repeated adjustments, although uncoordinated, eventually led to racial segregation in American cities.

Similarly, Thurner and colleagues' (2012) example can be systemically revisited and explained. In particular, Thurner et al. show that risk controls at local levels by individual lenders can collectively induce a significant instability in prices and involuntarily create more systemic risk. These local lenders, for instance, banks and other financial institutions, rationally adjust their individual leverage exposures of collateralized borrowers in order to avoid unnecessary risks, when the prices of the assets used as collateral are dropping. As a consequence of such uncoordinated adjustments of leverage exposures, margin calls are issued, leading to massive selling of collateralized assets at just the wrong time. Hence, dangerously spiked volatility in price fluctuations appears at the macro-level. Although the emergent property of the economic system as a whole does not seem derivable from the rationales and behaviours of individuals - the lenders, the emergence of the systemic volatility in price fluctuations can be readily seen by using Corollary 1 . Specifically, although in terms of absolute numbers, there are a few lenders when compared to the entire population, they in reality affect a large segment of the economy through their lending activities. That is, a large portion of the population is adversely disturbed by margin calls so that the resultant massive selling by individual borrowers eventually merges into a market-wide risk of large magnitude. In such a situation, even though the selling of individual borrowers seems to be uncoordinated on the surface, these individuals' actions in reality are unconsciously coordinated by the lenders, due to the overall small number of them.

\section{Macroscopic Organizations of Micro Economic Agents}

This section provides a theoretical explanation for how markets signal for additional competition and innovation. This helps various macro-level organizations, consisting of micro economic men and agents of inconsistent or even conflicting interests, to be organized. In other words, other than many socioeconomic phenomena that naturally emerge at the macro-level out of unintended and uncoordinated actions and interactions of micro economic men and agents (Delli Gatti et al., 2010; Farmer \& Foley, 2009); as discussed in the previous section, there are many entities in the business world that are organized purposefully to answer calls or 
invitations of various markets or to satisfy forever changing consumer demands (Forrest et al., 2017).

\section{Identification of market signals for new products and additional innovation}

First, let us examine how markets within the present business world call for new products and innovation. For this purpose, let us look at such a market that is served by $m$ incumbent firms with their mutually substitutable offerings, $m=1,2, \ldots$ Assume that each of these incumbent firms enjoys the backing of loyal customers who only purchase the offering provided by their favourite firm, as long as the price is no more than their reservation value. Within this market, the incumbent firms compete with each other over those customers, called switchers, who switch from the offering of one firm to that of another depending on whose price is more competitive. The price of a product here does not mean the absolute dollar value of a product. Instead, it stands for the price of per-unit value of a product. For example, the price of a pair of walkie talkies is a lot lower than that of two iPhones. However, other than functioning as equipment for shortdistance communications, an iPhone has many other capabilities. So, if one compares their prices of per-unit values, two iPhones are much lower priced than a pair of walkie talkies.

Considering how readily information and knowledge are available due to the rapid development of information and communication technology, assume that the pricing strategies of all interacting firms are known to each other so that the incumbent firms employ their best responses in terms of price by playing the Nash equilibrium through pure selfanalysis. Then, the following result holds true:

Theorem 2. In the Nash equilibrium of the afore-described market, if the segment of switchers is greater than the minimum loyal-customer base of the incumbent firms, then at least one new firm can gainfully enter the market by providing its substitute offering, and the total expected profit of all entering firms can be potentially as large as the profit of the incumbent with the smallest base of loyal customers.

The extremely technical proof of this result is given in the Appendix. In terms of the literature, a similar result as Theorem 2 is established by Forrest et al. (2017). However, in comparison, our result here generalizes the previous version in the following sense: The latter result is shown to hold under very strong conditions - the boundary conditions of all the incumbent firms are identical, where the firms' bases of loyal customers have the same magnitude, they have the same reservation prices, the same cost of production, the same sales price, the same amount of available resources, etc. Theorem 2 above holds true without being subject to any of these constraints.

In layman's language, Theorem 2 states that when there is a sufficient consumer surplus (or a large enough totality of switchers), new competition naturally appears, no matter what entry barriers the incumbent firms attempt to install.
That is, it is market characteristics that beget the introduction of new or improved products and innovations, that incite the aspiration of new entrants with the promise of potentially making more profits than at least some of the existing firms.

The conclusion in Theorem 2 can be applied practically in different ways. First, in the perspective of the incumbent firms in a relatively stable market, their market establishment places them in a state of mutual forbearance. They alleviate rivalry by dividing markets in proportion to their strengths (Bernheim \& Whinston, 1990). They discretely allow stronger ones to dominate market segments $n$ which they are less efficient (Li \& Greenwood, 2004). Such co-dependence of these incumbents helps de-escalate rivalry (Yu \& Cannella Jr., 2012) so that interfirm hostility declines (Haveman \& Nonnemaker, 2000). To protect their market territory and status, which means steady flows of profits, the incumbent firms need to stay vigilant regarding the magnitude of the segment of switchers. As soon as this magnitude grows into a sufficiently large scale, new competition will appear; and that will mostly likely disrupt the existing state of mutual forbearance among the incumbent firms. Therefore, these incumbents must continuously improve their offerings to satisfy consumers' continually evolving consumption preferences.

Second, in the perspective of firms that attempt to enter into a relatively stable market beyond those they had already established themselves, the large scale of the market segment of switchers indicates that all the available offerings in the marketplace cannot truly satisfy the demands of these particular consumers. Hence, entrepreneurial firms that attempt to enter into this or some other market need to creatively identify the preferences and needs of switchers, and determine their optimal entry timing (Zachary et al., 2015), defined as the order of entry into the existing market in various contextual referents. In terms of literature, Lieberman and Montgomery (1988) propose the concept of first-mover advantage. They believe that first (or early) movers enjoy extra time over later ones for them to establish and occupy market territories. That is, entry timing matters in terms of economic performance (Fosfuri et al., 2013). However, studies (e.g., Lieberman \& Montgomery, 2013; and references found there) also suggest that time equally benefits later entrants, because delayed entry helps firms avoid costly pitfalls experienced by earlier movers. So, empirical analyses reveal such a logic that it explains why first movers have advantages over later ones and, simultaneously, why later movers enjoy recompenses over earlier ones (Lévesque et al., 2013). To resolve such a predicament, Theorem 2 comes to the rescue. In particular, for entrepreneurs who want to start their own companies, they can purposefully develop their firms to enter such a market based on their innovative understanding of the market signal - the existence of a sufficiently large segment of switchers - and their designs and productions of creative solutions. For established business entities that look for a new market to enter, they need to delay their entry into such a market until the market situation clears and settles. Theorem 2 states that as long as they can compete with incumbent 
firms through advanced technology, more efficient management or other means, they will have a chance to make more profits than some of the established incumbent firms.

Third, when Theorem 2 is applied to an emerging market, such as the PC market in the 1970s and 1980s (Sobel, 1999), other than the fact that the population of consumers is not well defined, the market segment of switchers expands quickly. It grows in magnitude constantly without any bound in sight. In such a market, first and early movers, if they want to first survive and then succeed, have to aggressively reach out to potential consumers, many of whom would be switchers initially at least, in order to establish their corresponding bases of loyal customers, while lowering the number of switchers as much as possible. At the same time, it is prudent for established companies in the business world to simply wait until those poorly funded and/or inexperienced start-up firms have steadily developed the market before entering. Other than waiting for the formation of a new market with sufficient depth and width, Theorem 2 says that the patience of waiting can provide these companies, as later movers, with the expectation of higher profitability than some of the early movers. This conclusion aligns with Golder and Tellis (1993). In particular, after analyzing 500 products in 50 different product categories, they empirically find that pioneers take approximately $10 \%$ of the market share with approximately $50 \%$ of them failing outright, while early followers occupy approximately $28 \%$ of the market with only approximately $8 \%$ failures. Additionally, Theorem 2 supports Markides and Geroski (2005) in the conclusion that large, multi-business enterprises exploit slack resources and complementary capabilities to scale up their operation and bypass early entrants.

\section{Macro structures built on micro agents of inconsistent orientations}

No matter which case among those discussed in the previous subsection we look at, efforts to succeed in the market that signals for new competition and additional innovation have to start with forming macro-level organizations by employing micro-level individuals and component parts. In particular, for the case of a relatively stable market, one smart incumbent strategy is to uphold their established mutual forbearance with each other so that their corresponding flows of profits can be more or less readily maintained. To accomplish this goal, these incumbent firms need to organize their business efforts around protecting their market territories and status quos - a macro-level organizational structure - by effectively mobilizing their working units and individual employees - micro-level entities - towards a common goal.

For the case of ambitious start-ups that attempt to launch their operations by entering a relatively stable market, the entrepreneurs have to first organize intellectual manpower to creatively decipher the meaning of a market signal; second, design and produce a brand-new market offer that will potentially satisfy the market demand; and third, bring the final product onto the market. All these macro-level efforts require orienting micro-level individuals towards an identified purpose. As for the case of an emerging market, first and early movers have to develop their bases of customers and then that of loyal customers by introducing their innovative market offers, while established companies in the business world only enter when the market has developed its sufficient depth and width. All these macrolevel business attempts come to fruition through organized efforts of micro-level individuals.

In short, many macro-level systemic phenomena emerge naturally from micro-level component parts, as discussed in the previous section. At the same time, a lot of macro-level organizations, events and processes are purposively organized to answer market calls and to meet consumer demands by effectively mobilizing micro-level individuals and component parts. By comparing the two situations - one naturally emergent, and the other human-organized, we can see that the former amplifies micro-level individual properties, no matter how unintended and uncoordinated they might be, onto systemic phenomena. And the latter organically places micro-level individuals and component parts into functional organizations towards the realization of an identified goal. So, a natural question arises: how can micro-level individuals and component parts with inconsistent or even conflicting interests work together to accomplish an identified macro-level common goal?

To answer this question, we examine the following related questions individually: (i) why do micro-level individuals and component parts mostly possess their individually inconsistent or even conflicting interests? (ii) What method do firms effectively employ to orient their employees' otherwise divergent efforts into a unified force? (iii) How are micro-level individuals and component parts with individually inconsistent or even conflicting interests practically placed into a cohesive organization?

Regarding question (i), let us focus on how each individual person forms his/her system of beliefs and values during the person's formative years. As for a component part of a whole, its beliefs and values consist of those shared by the members of the component. In terms of the concept of personal systems of beliefs and values, it means a person's view on how the world functions and how s/he needs to behave in order to stay within moral boundaries. Because of the existence of such a belief-value system within each person's cognition, a person is recognized by others with his/her particular identity and integrity (Forrest, 2018, p. 302).

To help accomplish our goal here, let us borrow the systemic yoyo model of systems (Lin, 2009). Specifically, each system can be intuitively or figuratively imagined as a multidimensional entity as shown in Figure 3. This systemic intuition indicates that each entity, which is naturally a system according to Klir (2001), in the universe, be it physical or intellectual, and be it a tangible or intangible thing, a living being, an organization, a market, or an economy, can be intuitively seen as a kind of realization of a certain multi-dimensional spinning yoyo with both an eddy 
and a meridian field around. It remains in a spinning motion. If it stops its spinning, it will no longer exist as an identifiable system. For all detailed discussions on why this abstract yoyo structure behind each and every system exists, please consult with Lin (2009).

Figure 3. The abstract yoyo model of each system in 3dimensional space

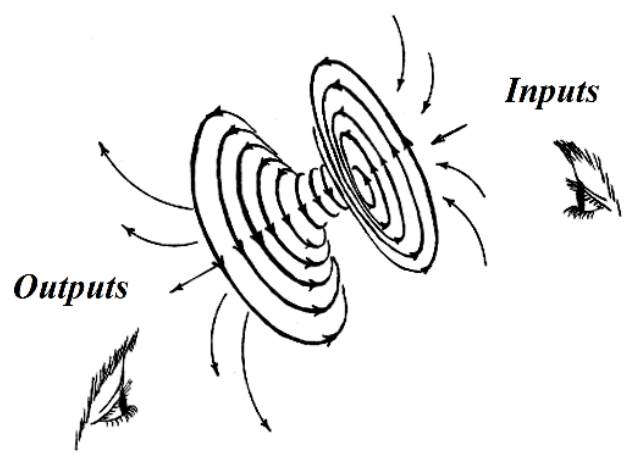

This yoyo model implies that each person lives in a large pool of spinning fields, which are the fields of other people, physical things, abstract thoughts, and a myriad of other matters. As soon as a person is born, his/her yoyo field starts to interact with many different yoyo fields. It is through these interactions with people, with physical objects, with abstract thoughts, and with the various other things and matters that the person develops his/her system of fundamental beliefs and values through employing the four inherent endowments: self-awareness, imagination, conscience, and free will. This situation of how a person forms his/her beliefs and values is similar to the way that a civilization formulates its value system (Lin \& Forrest, 2011). Within these interactions, there are always inevitable differences. That explains why each person has his/her own unique system of very specific beliefs and values. It is this specific belief-value system that dictates the person's decision making for the rest of his/her life. Although with time the belief-value system evolves with certain components updated while some others replaced, the most fundamental parts remain more or less constant. As for individually inconsistent or even conflicting beliefs and values, they generally stem from the differences in the environments within which people grow up and form their initial beliefs and values. Compared to the magnificent scale of the entire ocean of spin fields of the world, although differences in environments might be subtle or minor, they are still generally major to individuals involved. These environmental differences lead to important inconsistencies and conflicts in relevant personal belief-value systems. That explains systemically why, for example, children who grow up within the same household possess quite different, even conflicting personalities, characteristics, and thinking processes (Scott et al., 1991).

In terms of question (ii), what method(s) can firms effectively employ to orient their employees' efforts that are otherwise divergent into a unified force? The answer is that firms, which expect to successfully offer products in the consumer market, clearly state and rigorously commit to their missions.
In particular, in its mission, a firm plainly spells out its purpose of existence, including its values and beliefs, what it does and what the targeted market segment it serves. Because employees tend to have inconsistent or even conflicting beliefs and values, firms have to employ their missions and commit seriously to the missions to organically unite the otherwise divergent employee efforts towards the practical end of materializing their stated business goals. This approach has been confirmed as effective empirically by McGrath (2013) and theoretically by Forrest et al. (2020).

At this juncture, we need to note that although the goal of a firm might be to make as much profit as possible or contribute to the wellbeing of the society in a particular way, or others, the maximization of the business objective, as given in the mission statement, has to include the component of remaining competitive in the product market. This end is reinforced by Theorem 2, because only by maintaining its financial competitiveness in the marketplace, is a firm able to survive long enough to potentially materialize its mission. And only a financially solvent firm is able to materialize the non-economic goals of business.

As for question (iii), how are micro-level individuals and components with individually inconsistent or even conflicting interests practically placed into a cohesive organization? The answer lies in the systemic yoyo intuition in Figure 4. Specifically, the figure is the bird's eye view of the yoyo model of a general, market-oriented firm (Figure 3), where the entire dish spins in a counter clockwise direction, while each local eddy field models an employee's systemic structure, consisting of all elements in his/her system of beliefs and values and their associations. The different arrow directions model how individual employees display their inconsistent or even conflicting interests with each other.

Because each employee tends to have his/her own unique system of beliefs and values, we can readily see that for most employees, their personal belief-value systems will more or less disagree with the stated mission of the firm. Therefore, another question that naturally follows the one that is just addressed in the previous paragraph is: when a firm's mission is in conflict with the personal beliefs and values of an employee, can the firm still make use of the talent of the employee while keeping his/her well-being in mind? For this question, Figure 4 suggests that the answer to this question is: Yes, it is possible. As the conclusion of this section, we use the conventional method of microeconomics to reconfirm this answer.

Figure 4. The eddy field of a focal firm

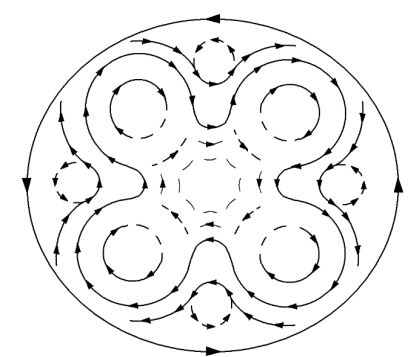


Assume that other than maximizing its objective, as defined in the written mission statement, the focal firm of our concern constantly examines how well its mission is accomplished. Let the aforementioned employee be $i$ and let $Y$ be such a variable that measures a particular aspect of $i$ 's personal system of beliefs and values that disagrees with the mission of the firm. In real life, although it is very possible that this variable $Y$ cannot be explicitly measured or even defined clearly, its existence is definitely unquestionable from the assumption that the firm's mission and employee $i$ 's personal belief-value system disagree with each other.

Let employee $i$ 's utility function be expressed as follows: $U_{i}=X_{i} Y$, the degree of accomplishment of the stated mission, be measured by the following mission function: mission $=X_{C} / Y$, where $X_{i}$ stands for the aggregate consumption of employee $i$, and $X_{C}$, the aggregate expenditure of the firm for running its business. Then the objective function of the firm can be particularly given by

$$
\begin{aligned}
\operatorname{obj}=\operatorname{obj}\left(U_{i}, \text { mission }\right) & =U_{i} \times \text { mission } \\
& =X_{i} \times X_{C},
\end{aligned}
$$

in which the particular variable $Y$ disappears. That means that although the firm's mission is in conflict with the personal belief-value system of employee $i$, in the objective function the firm still cares about employee $i$ as much as if the two do not have any conflict. The key here is that the firm has the freedom to define its objective function in an appropriate functional form. For relevant discussions on managerial efficiency, see Forrest and Orvis (2016).

\section{Conclusion}

This paper examines two diverging efforts that exist in the present literature regarding how to reshape the existing economic theories so that economists will be able to forecast the arrival of imminent economic crises in a timely fashion, provide policy makers with needed scholarly supports, among others (Delli Gatti et al., 2010; Vines \& Wills, 2018). Considering the fact that predicting natural disasters has been an unsettled world-class challenge to the entire world of natural science and mathematics (Lin \& OuYang, 2010), the effort of simply modifying the current system of equations in the benchmark New Keynesian DSGE model to forecast imminent economic crises (Vines \& Wills, 2018) is destined to be fruitless. In particular, most large-scale natural events play out through their processes without being disrupted by humans, no matter if their disastrous consequences are predicted or not. However, economic disasters are very different. They are reflexively influenced by human expectations; their courses of evolution are greatly and determinately affected by human participants' estimates and consequent actions (Soros, 2003). This end explains why the attempt of using a few simple DSGE equations (Smets \& Wouters, 2007), mathematically speaking, to forecast disruptively different outcomes of reflexive human processes based on any records of the past is practically impossible (Lin
\& OuYang, 2010). To this end, as a reference, it is necessary for us to note the following effort. For years, there was a wellfunded research centre for mid-term weather forecasts in Europe. This centre developed for its purpose of prediction a system of more than five million equations in over five million variables, while the actual forecasts of weather had experienced uncertainties in terms of both mathematics and actual predictions (Lorenz, 1993). For a similar reason, the effort of providing adequate scholarly supports for policy making is destined to be unsuccessful if the focus is only on revising the current DSGE model, because adequate policy making is essentially dependent on forecasts of the future (Forrest et al., 2020).

Failures of forecasting the future using the DSGE model or any modified equation-based future version are rooted in the fact that such efforts attempt to extrapolate either the past or the present into the future. Hence, any result of such forecast cannot and will not capture changes that are sudden and disruptively different from the past or the present (Wu \& Lin, 2002). That is the reason why this paper embraces and generalizes the approach of Delli Gatti et al. (2010) from merely employing concepts and methods of complexity and computer simulations to those of systems science.

Because of the novelty of the employed approach - systemic logic of thinking - and methodology, which is based on both set theory and game theory, this paper is able to develop

- A new way to interpret abstract conclusions of mathematics in terms of when some characteristics of micro-level individuals can give rise to macro-level phenomena of systemic wholes, as revealed by Delli Gatti et al. (2010; 2011) through using computer simulations; and

- How market sends out its invitations for new products and additional innovations and why new competition appears.

And on top of these outcomes, this paper theoretically explains

- How racial segregation in American cities appeared (Schelling, 1969) ;

- How risk controls at local levels by individual lenders can collectively induce a significant instability in prices and involuntarily create more systemic risk (Thurner et al., 2012); and

- How various macro firms are organized with micro economic men and agents, although these micro components have inconsistent or even conflicting interests.

In short, one main conclusion of this paper is that not all macro-level phenomena can have direct micro-foundation or micro-founded explanations, as believed by some economists since the 1970s (Blanchard, 2018; Lucas, 1976).

Potential future research, building on this paper, can examine, for example, (1) how individually inconsistent or 
even conflicting beliefs and values can be smoothly unified under the mission statement of a firm, while the naturally resultant adverse effects or relevant managerial inefficiency (Forrest \& Orvis, 2016) are reduced to a minimal level; (2) how an organizational culture conducive to a firm's market success (McGrath, 2013) can be successfully fostered on top of individually inconsistent or even conflicting beliefs and values; and (3) what particular methods of predicting economic crises can be developed on the idea of structural changes (Lin \& OuYang, 2010) instead of current extrapolation of the past or present into the future (Vines \& Wills, 2018).

\section{Appendix: Proof of Theorem 2}

For incumbent firm $i$, its selling price $P_{i}$ satisfies $C_{i} \leq P_{i} \leq M_{i}$, where $C_{i}$ is the cost of production and $M_{i}$ the maximum selling price, which is equal to the reservation price of loyal customers. Hence, there is $\alpha_{i} \in[0,1]$ such that $P_{i}=C_{i}+$ $\alpha_{i}\left(M_{i}-C_{i}\right), i=1,2, \ldots, m$. For the rest of the proof, instead of $P_{i}$, the incumbent firms compete by adjusting $\alpha_{i}, i=$ $1,2, \ldots, m$. Without confusion, we will use $P_{i}$ in the place of $\alpha_{i}$, where all costs of production and maximum selling prices are respectively normalized to 0 and 1 .

In terms of performance, each incumbent firm is constrained by its available resources (Harmancioglu et al., 2009; Barney \& Arikan, 2001) and how the resources are mobilized (Peteraf \& Barney, 2003; Forrest et al., 2020). If the factors involved in business operation include $x_{1}, x_{2}, x_{3}, \ldots$, then for incumbent firm $i(=1,2,3, \ldots, m)$, the magnitude $N_{i}\left(x_{1}, x_{2}, x_{3}, \ldots\right)$ of its loyal-customer base is bounded at the upper and lower sides: $L_{i}\left(x_{1}, x_{2}, x_{3}, \ldots\right) \leq N_{i}\left(x_{1}, x_{2}, x_{3}, \ldots\right) \leq U_{i}\left(x_{1}, x_{2}, x_{3}, \ldots\right)$, where $L_{i}$ is the lower ends and $U_{i}$ the upper bound. That is, there is a unique number $\beta_{i} \in[0,1], i=1,2, \ldots, m$, satisfying that $N_{i}\left(x_{1}, x_{2}, x_{3}, \ldots\right)=L_{i}\left(x_{1}, x_{2}, x_{3}, \ldots\right)+\beta_{i}\left[U_{i}\left(x_{1}, x_{2}, x_{3}, \ldots\right)-L_{i}\left(x_{1}, x_{2}, x_{3}, \ldots\right)\right]$. Hence, the magnitude $N_{i}$ of firm $i$ 's loyal-customer base can be normalized to $\beta_{i} \in[0,1]$ such that the segment of switchers is of the magnitude $\beta$ such that $\beta=$ $1-\sum_{i=1}^{m} \beta_{i}$ and $0 \leq \beta \leq 1$. In the rest of the proof, these normalized parameters are used.

In Nash equilibrium, the given market does not have any pure strategy of pricing for the incumbent firms. In fact, for any portfolio $\left(x_{1}, x_{2}, \ldots, x_{m}\right)$ of pure strategies of prices, let $i_{1}, i_{2}, \ldots, i_{k} \in\{1,2, \ldots, m\}$ such that $1 \leq k \leq m$ and $x_{i_{1}}=x_{i_{2}}=\cdots=$ $x_{i_{k}}<x_{j}$, for $j \in\{1,2, \ldots, m\}$ and $j \neq i_{s}, s=1,2, \ldots, n$. If $k=1$, then firm $i_{1}$ has ready won over all switchers and can therefore slightly raise its price $x_{i_{1}}$ to bring in additional profits as long as the new price is still the lowest. If $1<k \leq m$, then one of the firms $i_{1}, i_{2}, \ldots, i_{k}$ can lower its price slightly to create additional profits by attracting all switchers. Therefore, the portfolio $\left(x_{1}, x_{2}, \ldots, x_{m}\right)$ of pure strategies is not a Nash equilibrium.

Let $F_{i}(P)$ be the price distribution of incumbent firm $i$ with price $P$. Then, in Nash equilibrium, our market has a unique portfolio $\left(F_{1}(P), F_{2}(P), \ldots, F_{m}(P)\right)$ of mixed strategies, where for $k=1,2,3, \ldots$,

$F_{k}(P)=1-\frac{1}{\beta_{k}}\left(\frac{(1-P) \prod_{i=1}^{m} \beta_{i}}{\beta P}\right)^{\frac{1}{m-1}}, F_{k}(1)=1, F_{k}\left(\frac{\beta_{k}}{\beta_{k}+\beta}\right)=0$.

In fact, the objective of firm $k$ is to maximize its expected profit from its loyal customers and its share of switchers by selecting an appropriate price distribution $F_{k}(P)$ :

$\max _{F_{k}(P)} E\left(\Pi_{k}\right)=\int_{-\infty}^{+\infty}\left\{\beta_{k} P+\prod_{i=1, i \neq k}^{m}\left[1-F_{i}(P)\right] \beta P\right\} d F_{k}(P)$

where $\Pi_{k}$ is firm $k$ 's profit, $E\left(\Pi_{k}\right)$ its expected profit. Hence, the equilibrium indifference condition for firm $k$ is

$\beta_{k} P+\prod_{i=1, i \neq k}^{m}\left[1-F_{i}(P)\right] \beta P=\beta_{k}, k=1,2,3, \ldots$

which implies

$\prod_{j=1, j \neq i}^{m}\left[1-F_{j}(P)\right]=\beta_{k}(1-P) /_{\beta P}, i=1,2, \ldots, m$.

Dividing the first equation by the jth in equation (12) produces

$1-F_{j}(P)=\frac{\beta_{1}}{\beta_{j}}\left[1-F_{1}(P)\right], j=2,3, \ldots, m$. 
Substituting equation (13) into equation (11) leads to the following, and so equation (9) follows:

$\beta_{1}\left[1-F_{1}(P)\right]=\left(\frac{(1-P) \prod_{i=1}^{m} \beta_{i}}{\beta P}\right)^{\frac{1}{m-1}}$.

The second part of equation (9) can be checked directly. For the second part, firm $k$ needs to attract as many switchers as possible to increase its profits from the guaranteed level $\beta_{k}$ by charging from its loyal consumers the reservation value 1 . So, $\beta_{k} P+\beta P \geq \beta_{k}$, which implies $P \geq \beta_{k} /\left(\beta_{k}+\beta\right)$. Hence, the third part of equation (9) follows.

When the afore-described market is in the Nash equilibrium, all the normalizations above jointly imply that $\beta_{i}=\beta_{1}, i=$ $2,3, \ldots, m$. In fact, these $\beta_{i}$ s are not all equal to each other, let $\beta_{k}=\max \left\{\beta_{1}, \beta_{2}, \ldots \beta_{m}\right\}$ and $\beta_{k}>\beta_{k_{0}}$, for $k$ and $k_{0}$ satisfying $1 \leq k, k_{0} \leq m$. Then, equations (10), (11) and (9) jointly imply that the expected profit of firm $k$ in the Nash equilibrium is

$$
\begin{aligned}
& E\left(\Pi_{k}\right)=\int_{-\infty}^{+\infty}\left\{\beta_{k} P+\prod_{j=1, j \neq k}^{m}\left[1-F_{j}(P)\right] \beta P\right\} d F_{k}(P)=\int_{\frac{\beta_{k}}{\beta_{k}+\beta}}^{1} \beta_{k} d F_{k}(P)=\left.\beta_{k} F_{k}(P)\right|_{\frac{\beta_{k}}{\beta_{k}+\beta}} ^{1} \\
& =\beta_{k}\left\{\frac{1}{\beta_{k}}\left[\frac{\left(1-\frac{\beta_{k}}{\beta_{k}+\beta}\right) \prod_{j=1}^{m} \beta_{j}}{\frac{\beta \beta_{k}}{\beta_{k}+\beta}}\right]^{\frac{1}{m-1}}\right\}=\left(\prod_{j=1, j \neq k}^{m} \beta_{j}\right)^{\frac{1}{m-1}} .
\end{aligned}
$$

The meaning of loyal customers and the existence of $k_{0}$ jointly imply

$E\left(\Pi_{k}\right)=\left(\prod_{j=1, j \neq k}^{m} \beta_{j}\right)^{\frac{1}{m-1}} \geq \beta_{k}=(\underbrace{\beta_{k} \beta_{k} \ldots \beta_{k}}_{m-1 \text { times }})^{\frac{1}{m-1}}>\left(\prod_{j=1, j \neq k}^{m} \beta_{j}\right)^{\frac{1}{m-1}}=E\left(\Pi_{k}\right)$,

which is a contradiction. Hence, all loyal-customer bases of the incumbent firms must have the same magnitude, which is denoted as $\alpha$. So, equation (9) implies that in Nash equilibrium, the afore-described market has a unique symmetric portfolio $\left(F_{1}(P), F_{2}(P), \ldots, F_{m}(P)\right)$ of pricing strategies, where $F_{k}(P)=F(P)$, for $k=1,2,3, \ldots$

To complete the proof of Theorem 2, assume without loss of generality that one new firm only enters the market by uniformly randomizing its price $P$ between the production cost and the expected maximum selling price. The previous discussion indicates that all these variables can be normalized into $P \in[0,1]$.

To deal with the market disruption caused by the entrant, each of the $m$ incumbent firms sets its price by considering those of all rivals, including the entrant and other incumbent firms. So, equations (9) and (11) jointly produce the following equilibrium indifference condition of incumbent firm $k$

$\beta_{k} P+\beta P(1-P) \prod_{j=1, j \neq k}^{m}\left[1-F_{j}(P)\right]=\beta_{k}$.

From this equation, $\beta_{k}=\alpha$ and $F_{k}(P)=F(P), k=1,2,3, \ldots$, we obtain

$F(P)=1-\left(\frac{\alpha}{\beta P}\right)^{\frac{1}{m-1}}$

which is defined when $1 \geq P \geq \alpha / \beta$. Hence, the expected profits of the entrant is

$E_{e}(\Pi)= \begin{cases}\frac{-m}{2(m-2)} \frac{\alpha^{2}}{\beta}+\frac{m-1}{m-2} \frac{\alpha^{\frac{m}{m-1}}}{\beta^{\frac{1}{m-1}}}+\beta\left(\frac{\alpha}{\beta}\right)^{\frac{m}{m-1}}, & \text { if } m \geq 3 \\ \frac{\alpha^{2}}{2 \beta}-\frac{\alpha^{2}}{\beta} \ln \frac{\alpha}{\beta}+\beta\left(\frac{\alpha}{\beta}\right)^{\frac{m}{m-1}}, & \text { if } m=2\end{cases}$

And the expected profit of any of the $m$ incumbent firms is

$$
\begin{aligned}
& E_{m}(\Pi)=\int_{\alpha / \beta}^{1}\left\{\alpha \times P+\beta \times P(1-P) \prod_{j \neq i}^{m}[1-F(P)]\right\} d F(P)+\alpha \times\left(\frac{\alpha}{\beta}\right)^{\frac{1}{m-1}} \\
& =\int_{\alpha / \beta}^{1} \alpha d F(P)+\alpha\left(\frac{\alpha}{\beta}\right)^{\frac{1}{m-1}}=\alpha .
\end{aligned}
$$


Now, it is ready to check that $\frac{\partial}{\partial \alpha}\left[E_{e}(\Pi)-E_{m}(\Pi)\right]>0$ and that when $\alpha=1 /(m+1)=\beta, E_{e}(\Pi)-E_{m}(\Pi)>0$. Hence, there is $\alpha^{*} \in(0,1 /(m+1))$ such that when $\alpha \geq \alpha^{*}$, the expected profits $E_{e}(\Pi)$ of the entering firm is greater than that $E_{m}(\Pi)$ of any of the incumbent firms. So, the conclusion of Theorem 2 follows.

\section{References}

Allen, F., \& Gale, D. (2001). Financial contagion. Journal of Political Economy, 108,1-33. https://doi.org/10.1086/262109

Barney, J., \& Arikan, A. (2001). The resource-based view: Origins and implications. In M. Hitt, R. Freeman, \& J. Harrison (Eds.), Handbook of strategic management (pp. 124-185). Oxford, UK: Blackwell.

Battiston, S., Delli Gatti, D., Gallegati, M., Greenwald, B. \& Stiglitz, J. (2007). Credit chains and bankruptcies avalanches in supply networks, Journal of Economic Dynamics and Control, 31, 2061-2084. https://doi.org/10.1016/j.jedc.2007.01.004

Bernheim, B.D., \& Whinston, M.D. (1990). Multimarket Contact and Collusive Behavior. RAND Journal of Economics, 21, $1-26$.

Blanchard, O. (2018). On the future of macroeconomic models. Oxford Review of Economic Policy, 34(1-2), 43-54. https://doi.org/10.1093/oxrep/grx045

Boissay, F. (2006). Credit chains and the propagation of financial distress. European Central Bank, Working Paper No. 573.

Delli Gatti, D., Desiderio, S., Gaffeo, E., Cirillo, P. \& Gallegati, M. (2011). Macroeconomics from the Bottom-Up. Milan: Springer. https://doi.org/10.1007/978-88-470-1971-3

Delli Gatti, D., Gaffeo, E. \& Gallegati, M. (2010). Complex agent-based macroeconomics: a manifesto for a new paradigm. Journal of Economic Interaction and Coordination, 5(June), 111-135. https://doi.org/10.1007/s11403010-0064-8

Farmer, D., \& Foley, D. (2009). The economy needs agent-based modelling. Nature, 460, 685-686. https://doi.org/10.1038/460685a

Forrest, J.YL. (2018). General Systems Theory: Foundation, Intuition and Applications in Business Decision Making. Switzerland: Springer. https://doi.org/10.1007/978-3-030-04558-6

Forrest, YL.J., Buttermore, J., \& Wajda, T.A. (2017). At Nash equilibrium when new market competitions appear? Kybernetes, The International of Cybernetics, Systems and Management Science, 46(2), $256-271$. https://doi.org/10.1108/K-11-2016-0311

Forrest, J.Y-L., Duan, X.J., Zhao, C.L., \& Xu, L.D. (2013). Systems Science: Methodological Approaches. New York: CRC Press, an imprint of Taylor and Francis.

Forrest, J.YL., Nicholls, J., Schimmel, K., \& Liu, S.F. (2020). Managerial Decision Making: A Holistic Approach. Switzerland: Springer. https://doi.org/10.1007/978-3-030-28064-2

Forrest, J.Y-L., \& Orvis, B. (2016). Principles of management efficiency and organizational inefficiency. Kybernetes: The International Journal of Cybernetics, Systems and Management Sciences, 45(8), $1308-1322$. https://doi.org/10.1108/K-03-2016-0035

Fosfuri, A., Lanzolla, G., \& Suarez, F.F. (2013). Entry-timing strategies: The road ahead. Long Range Planning, 46, 300311. https://doi.org/10.1016/j.lrp.2013.07.001

Golder, P.N., \& Tellis, G.J. (1993). Pioneer advantage: Marketing logic or marketing legend? Journal of Marketing Research, 30, 158-170. https://doi.org/10.1177/002224379303000203

Hall, A.D., \& Fagen, R.E. (1956). Definitions of systems. General Systems, 1, 18-28.

Harmancioglu, N., Droge, C., \& Calantone, R. (2009). Strategic fit to resources versus NPD execution proficiencies: What are their roles in determining success? Journal of the Academy of Marketing Science, 37(3), $266-282$. https://doi.org/10.1007/s11747-008-0125-X

Haveman, H.A., \& Nonnemaker, L. (2000). Competition in multiple geographic markets: The impact on growth and market entry.Administrative Science Quarterly, 45(2), 232-267. https://doi.org/10.2307/2667071

Klir, G. (2001). Facets of Systems Science, New York: Springer. https://doi.org/10.1007/978-1-4615-1331-5

Kuratowski, K., \& Mostowski, A. (1976). Set Theory: With an Introduction to Descriptive Set Theory. Amsterdam: NorthHolland.

Lévesque, M., Minniti, M., \& Shepherd, D. (2013). How late should Johnny-come-lately come? Long Range Planning, 46, 369-386. https://doi.org/10.1016/j.lrp.2013.06.004

Li, S.X., \& Greenwood, R. (2004). The effect of within industry diversification on firm performance: Synergy creation, multimarket contact and market structuration. Strategic Management Journal, 25, 1131-1153. https://doi.org/10.1002/smj.418

Lieberman, M.B., \& Montgomery, D.B. (1988). First-mover advantages. Strategic Management Journal, 9, 41-58. https://doi.org/10.1002/smj.4250090706 
Jeffrey Yi-Lin Forrest, Zaiwu Gong, Erkan Köse, Diane D. Galbraith, Oğuzhan A. Arık: An Economy's Emergent Properties and How Micro Agents with Inconsistent or Conflicting Interests Are Holistically Organized into Macro Entities

Lieberman, M.B., \& Montgomery, D.B. (2013). Conundra and progress: Research on entry order and performance. Long Range Planning, 44, 312-324. https://doi.org/10.1016/j.lrp.2013.06.005

Lin, Y. (1987). A model of general systems. Mathematical Modelling: An International Journal, 9(2), 95-104. https://doi.org/10.1016/0270-0255(87)90518-5

Lin, Y. (1988). An application of systems analysis in sociology. Cybernetics and Systems: An International Journal, 19, 267278. https://doi.org/10.1080/01969728808902168

Lin, Y. (1999). General Systems Theory: A Mathematical Approach. New York, NY.: Kluwer Academic/Plenum Publishers.

Lin, Y. (2009). Systemic Yoyos: Some Impacts of the Second Dimension. Boca Raton, FL.: CRC Press.

Lin, Y., \& Forrest, B. (2011), Systemic Structure behind Human Organizations: From Civilizations to Individuals, New York: Springer.

Lin, Y., \& OuYang, S.C. (2010). Irregularities and Prediction of Major Disasters. New York: CRC Press, an imprint of Taylor and Francis. https://doi.org/10.1201/9781420087468

Lorenz, E. N. (1993). The Essence of Chaos. Seattle: Washington University Press.

Lucas, R. (1976). Econometric policy evaluation: A critique. Carnegie-Rochester Conference Series on Public Policy, 1,1946. https://doi.org/10.1016/S0167-2231(76)80003-6

Markides, C.C., \& Geroski, P.A. (2005). Fast second: How smart companies bypass radical innovation to enter and dominate new markets. San Francisco: Jossey Bass/Wiley.

McGrath, R.G. (2013). The End of Competitive Advantage: How to Keep Your Strategy Moving as Fast as Your Business. Boston: Harvard Business Review Press.

Peteraf, M., \& Barney, J. (2003). Unraveling the resource-based tangle. Managerial and Decision Economics, 24(4), 309323. https://doi.org/10.1002/mde.1126

Schelling, T.C. (1969). Models of segregation. American Economic Review, 59(2), 488-493.

Scott, W.A., Scott, R., \& McCabe, M. (1991). Family relationships and children's personality: A cross-cultural, cross-source comparison. British Journal of Social Psychology, 30(1), 1-20. https://doi.org/10.1111/j.2044-8309.1991.tb00919.x

Smets, F., \& Wouters, R. (2007). Shocks and frictions in US business cycles: A Bayesian DSGE approach. American Economic Review, 97(3), 586-606. https://doi.org/10.1257/aer.97.3.586

Sobel, R. (1999). When Giants Stumble: Classic Business Blunders and How to Avoid Them. Paramus, New Jersey: Prentice Hall.

Soros, G. (2003). The Alchemy of Finance. New York, NY: Wiley.

Thurner, S., Farmer, D. \& Geanakoplos, J. (2012). Leverage causes fat tails and clustered volatility. Quantitative Finance, 12(5), 695-707. https://doi.org/10.1080/14697688.2012.674301

Vines, D., \& Wills, S. (2018). The rebuilding macroeconomic theory project: An analytical assessment. Oxford Review of Economic Policy, 34(1-2), 1-42. https://doi.org/10.1093/oxrep/grx062

von Bertalanffy, L. (1968). General Systems Theory. New York, NY: George Braziller.

Wu, Y., \& Lin, Y. (2002). Beyond Nonstructural Quantitative Analysis: Blown-Ups, Spinning Currents and the Modern Science. River Edge, New Jersey: World Scientific. https://doi.org/10.1142/4877

Yu, T., \& Cannella, A.A., Jr. (2012). A comprehensive review of multimarket competition research. Journal of Management, 39, 76-109. https://doi.org/10.1177/0149206312462456

Zachary, M. A., Gianiodis, P. T., Payne, G. T., \& Markman, G. D. (2015). Entry timing: Enduring lessons and future directions. Journal of Management, 41(5), 1388-1415. https://doi.org/10.1177/0149206314563982

\section{Razvijajoče se lastnosti gospodarstva in kako so mikro agenti z nepredvidljivimi ali nasprotujočimi si interesi celostno organizirani v makro entitete}

\section{Izvleček}

Obstoječa literatura navaja, da računalniške simulacije lahko razkrijejo, kako značilnosti posameznikov na mikro ravni povzročajo pojav sistemske celote na makro ravni. Ta študija želi vzpostaviti to pomembno simulacijsko opazovanje kot teoretični rezultat s trdnimi temelji. Poleg tega, da obravnavamo, kdaj lahko celostni pojavi naravno izhajajo iz značilnosti mikro nivoja, ta študija raziskuje, kako in zakaj se zdi, da se številni subjekti na makro ravni odzivajo na tržne klice z organskim zbiranjem agentov na mikro ravni v enotno usmerjene operativne celote, čeprav imajo ti agenti nedosledne ali celo nasprotujoče si interese. Ta študija razvija zaključke, ki temeljijo na rezultatih sistemske znanosti, in določajo zadosten pogoj, pod katerimi lahko lastnosti agentov na mikro ravni naravno vodijo do pojava lastnosti makro nivoja sistemske celote, čeprav so prve heterogene in se obnašajo nepredvideno ter nekoordinirano. Ta študija predlaga, da se vsak teoretični rezultat ekonomije ukorenini na osnovnih dejstvih osebnih sistemov prepričanj in vrednot ter razširja metode omrežij in računalniških 
simulacij na metode sistemske znanosti. Pojasnjuje, kdaj makro družbenoekonomski pojavi nastanejo zaradi nepredvidenih in nekoordiniranih dejanj ter interakcij ljudji na mikroekonomski ravni. Ponuja splošnejši pristop za oblikovanje zanesljivih zaključkov kot tisti, ki jih opazimo pri računalniških simulacijah. Dodatno določa pogoje, kdaj se lahko gospodarski subjekti na makro ravni odzivajo na tržne pozive, in kako se lahko posamezniki na mikro ravni z nepredvidenimi ali celo nasprotujočimi si interesi organsko združijo v operativne poslovne organizacije.

Ključne besede: konkurenca, nastanek, celostni pojavi, tržni signal, sistem, vrednost, jojo model 